Author's post-print (i.e. final draft post-refereeing) - see http://www.sherpa.ac.uk/romeo/issn/0038-2876/. Publisher's version available at http://saq.dukejournals.org/content/113/2/313.abstract - please cite the latter.

\title{
Lost in Space? Lefebvre, Harvey and the Spatiality of Negation
}

\author{
Greig Charnock ${ }^{1}$
}

It's all fine and good...to evoke relational conceptions such as the proletariat in motion or the multitude rising up. But no one knows what any of that means until real bodies go into the absolute spaces of the streets...at a particular moment in absolute time.

...To neglect that connectivity is to court political irrelevance (David Harvey, Rebel Cities).

What, if anything, is intrinsically spatial about saying 'no' to austerity, or to capitalism generally? It certainly appears that the urban character of recent popular uprisings - from Tahrir Square to Syntagma Square; from Puerta del Sol to Zuccotti Park - suggest that there is some necessarily spatial dimension to contemporary forms of revolt. John Holloway suggests that interstitial revolution can be usefully thought of in terms of 'cracks': moments of refusal (of 'the No') that reveal the possibility of a (not-yet-)existing world built on dignity and mutual recognition rather than upon abstract labor and the command of money. 'Perhaps the most obvious way of thinking of cracks is in spatial terms', proposes Holloway (2010: 27): 'Here ... we shall not accept the rule of capital or the state, we shall determine our own activity'.

This paper is motivated by Holloway's part-spatial conceptualization of cracks, but also out of an engagement with two avowedly dialectical and Marxist thinkers of space whose works have found contemporary resonance in the anti-austerity-related slogan of 'the right to the city': Henri Lefebvre and David Harvey. In searching for initial clues to the connectivity between time, space and negation, I find that the two versions of the production of space offered up by Lefebvre, on the one hand, and Harvey, on the other, are not as easily 
reconcilable as one might be led to think. Both thinkers open the door to markedly different - and, in their own way, problematic - notions of the critique of capitalist space and of the spatiality of emancipatory politics.

\section{Lefebvre: Negative Critique and the Spatiality of (Dis-)Alienation}

Prior to the 'discovery' of the works of Henri Lefebvre by Anglophone scholars in the 1990s, his reception in France and elsewhere was primarily as someone who wrote about dialectical method (Shields 1999: 109). A hallmark of Lefebvre's writings is therefore the extent to which they are consistently methodologically minded, the dialectic being the thread that runs through his prolific and thematically varied output over several decades. This is certainly the case with his writings on space, originally published between 1968 and 1974. In these, and in addition to arguing persuasively that space should be thought of in dialectical terms of its social production - rather than in purely Cartesian and Euclidean terms Lefebvre's signal methodological contribution is to highlight the anti-representational orientation of Hegelian Marxism (see Charnock and Ribera-Fumaz 2011). That is, his critique of 'formal logic' emphasized at once the dialectic's ability to reconcile social scientific analysis with flux, inner relations, determinate negation, mediation and Becoming, while also exposing the 'terrorism' inherent to dominant, representational norms of analysis based upon purely formal or speculative methods of abstraction. For Lefebvre, representational knowledge about the world is but an ideological product of the will to abstract from concrete, lived experience (du vécu) (e.g. Lefebvre 1991: 230). Time and again, Lefebvre reveals the limits to formal logic, but also at the level of serviceable representations that have a 'real' and violent effect. In his work on space and urbanism, Lefebvre therefore railed against 'models' - abstract but concretely applicable representations of a projected, planned society in which some kinds of social and spatial practice are condoned and others dismissed as pathological or dysfunctional. Lefebvre's work therefore reinforces that aspect of the dialectic which Marx demonstrated in his own critique of political economy: that it has the power to offer an understanding of the real movement of society whilst also exposing even the most developed form of non-dialectical consciousness of that society to be ideology and necessarily in the service of the reproduction of alienation.

Lefebvre's antidote to formal logic, speculative philosophies, structuralism, existentialism, and Soviet Diamat was what he repeatedly calls 'metaphilosophy' (see Charnock 2010). At 
root, metaphilosophy is concerned with praxis: 'Production produces man. So-called "world history" or the "history of the world" is nothing but the history of man producing himself, of man producing both the human world and the other man, the (alienated) man of otherness, and his self (his self-consciousness)' [sic] (Lefebvre 2008: I, 237). The purpose of critique, for Lefebvre, is therefore to illuminate and decipher human alienation on the basis of praxis (ibid.: 137); it is to ask: 'How can men live as they are living, and how can they accept it?' [sic] (ibid.: 30). Lefebvre's own exploration of this question led him to develop his critique of everyday life over the course of four decades, and to his work on the production of (urban) space.

Lefebvre's gambit in his 1968-74 writings is his assertion that 'urbanization' has superseded 'industrialization' - an historical process he claims Marx could not have foreseen, situated as he was within an epoch of 'competitive capitalism' (Lefebvre 1976: 10). Lefebvre explains that capitalism gave birth to urbanization as an 'active abstraction' (Kerr 1994: 28); in a sense, a wayward and patricidal offspring of industrialization (Lefebvre, 2000: 47; Merrifield 2011a: 469). Motivated by what he judged to be an insufficient attention to space in Marx and Marxism generally (Elden 2004a: 184-186) - as well as his own immersion in architectural and urbanist milieus from the late 1960s (Stanek 2011) - Lefebvre sought to show how capitalism produces its own abstract space - materially and in ideological, representational terms - and, in so doing, creates the permissive conditions for the reproduction of the relations of production according to their own immanent requirements and not simply those that feed and support the production of surplus-value in the factories (Lefebvre 1976). Time has been 'reduced' to constraints of space - circumscribed and suppressed within the abstract space of the urban form. The process of mediation that reproduces the relations of production in a contradictory form, according to Lefebvre, is therefore that of urbanization - the production of (urban) space.

'This, then, is what is new and paradoxical, explains Lefebvre (1976: 17): 'the dialectic is no longer attached to temporality ... To recognize space, to recognize what "takes place" there and what it is used for, is to resume the dialectic; analysis will reveal the contradictions of space'. Praxis and production are still at the root of Lefebvre's analysis, and it should be stressed that class struggle and bourgeois class strategy (directed through the homogenizing, 'terrorizing' power of the state) still has a large part to play in his depiction of the urban mode of existence as one of 'permanent crisis' (Lefebvre 2003; 2008: III). Lefebvre remains committed to tracing 
the movement of (dis-)alienation and in putting to work 'the critical labor of the negative' (Zuss 2005). According to Lefebvre we should view space in contradictory terms - difference being necessarily constitutive of urbanization, notwithstanding its homogenizing drive to concretize 'abstract space'. Lefebvre traces 'the existence of irreducibles, contradictions and objections that intervene and hinder the closing of the circuit [of everyday life], that split the structure' (Lefebvre 2000: 75). In his view, then, there is some residuum of human subjectivity and style that capital has been unable to subsume, invert or control, and it is this insight which holds the key to understanding the contradictions inherent to the production of abstract space.

Lefebvre's now famous clarion call for the 'right to the city' was, therefore, one that he bequeathed to urban subjects brought together under the centralizing and homogenizing process of urbanization but subjected to a programmed circuit of everyday life in, what he termed, the 'bureaucratic society of controlled consumption' (Lefebvre 2000). The working class remains the revolutionary subject for Lefebvre - not exclusively because of its exploitation as the source of labor-power or its relation to the development of the productive forces in industry, but because 'it gathers the interests ... of the whole society and firstly of all those who inhabit (Lefebvre 1996: 158). Ultimately, then, Lefebvre's recourse to Heidegger reveals the extent to which the class struggle is now no longer necessarily a struggle against capital; rather, the struggle is against the reduction of inhabiting (babiter, wohnen) to habitat (Elden 2004b: 96), and against the production of space as determined by anything other than generalized self-management (autogestion) of all urban citizens on the basis of the mutual recognition of difference and particularity.

Ultimately, for Lefebvre, an urban revolution remained only a possibility - albeit one which has been revealed in all too transient, explosive 'moments' such as that of the events of May 1968. Like Holloway's cracks, Lefebvre's moments attest to the interstitial character of revolution, and resonate, perhaps, with Adorno's methodological preoccupation with 'opening the non-conceptual within the concept' (Bonefeld 2012: 130). However, unlike Bonefeld and Holloway, who cling to time as the locus of critique, Lefebvre suggests that the critical labor of the negative should necessarily be aimed at space: '(Social) space is a (social) product, asserts Lefebvre (1991: 26); and 'there is a politics of space because space is political' (Lefebvre 2009: 174). As one critic corroborates, 'Lefebvre attempts to develop a method which is able to apprehend social space as such, in its genesis and its form, with its own 
specific time or times (the rhythm of daily life), and its particular centers and, what Lefebvre calls, polycentrism (agora, temple, stadium, etc)' (Kerr 1994: 25). This reading of Lefebvre's identification of the social content of spatial forms as being the key to 'the possible', and to the extent that he finds the Marxian critique of political economy to be a once necessary but, now, insufficient and misdirected endeavor, has profound implications for both critique and emancipatory politics.

\section{The Limits to Lefebvre}

There are several possible objections to Lefebvre's arguments. One might justifiably criticize Lefebvre for merely asserting, and never explicitly explaining, the salience of the urban problematique (Harvey 1974: 239). One might also raise concerns about the 'contextual boundedness' of aspects of Lefebvre's work (Brenner 2008: 242), insofar as it is of its time (steeped in frustration with everyday life in Gaullist France). Alternatively, Lefebvre has been dismissed as but another outmoded Marxist whose 'social critique' has been rendered obsolete by the transformation to flexible capitalism and the transformation of the 'subaltern subjectivity' of the 'liberated individual' (Ronneberger 2008). But I want to highlight fundamental issues with Lefebvre's 'application' of his dialectical logic to 'the urban' and to space from the perspective of the critique of political economy; a Marxian interrogation of Lefebvre's Marxism, in other words.

The basis of an arraignment against Lefebvre is already suggested in Smith's (1990: 92, 189 fn. 46) passing reference to Lefebvre's 'reproductionism', and to his drawing of too marked a distinction between the development of the forces of production versus the social relations of production. But this is more developed in a little-known article by Derek Kerr. In this, he surmises of Lefebvre $(1976 ; 1991)$ that: 'Class struggle and history are reduced to abstract time and exist in the container of abstract space, while this space has contradictions of its own which can then externally "envelop historical contradictions". But by separating out contradictions of space from those in space and by reducing class struggle and history to the latter, it is not clear what constitutes the contradictions of space'. He continues: 'If social relations are inherently spatial and temporal then there can be no separation in/of dualism' (Kerr 1994: 32); furthermore, to 'displace time by space merely obscures the dynamic and contradictory nature of the capital relation and the ways in which this expresses itself in a 
spatially uneven way through "the production of space in its own image" (ibid.: 34). Against Lefebvre, Kerr argues:

Marx was not limiting himself to time, but to uncovering the contradictory constitution of the capital relation (see Bonefeld 1993) as it attempts to transform and express itself through spatial and temporal modalities of existence. It is the capital relation that continually attempts to subordinate the whole (space) of society to the abstract logic of linear time, the ticking of the factory clock. This abstract time is not the concrete history of capitalism, but rather is the dominant and contradictory tendency through which that history expresses itself, one which continually attempts to reduce the internally related and qualitative nature of both space and time to the quantitative metric of value. As such the form, nature and very existence of "capitalist space" expresses and adheres in and through the contradictory presence of labor in capital. This is the dialectic, not one of time nor of space but ... a negative dialectic, a dialectic of negation with no certain synthesis ... The history of capitalism is, therefore, none other than the struggle over and through space as capital attempts to transform the entire spatial existence of society into a machine for the production and quantitative expansion of surplus value in terms of the metric of socially necessary labor time (ibid.: 32).

Ultimately, Kerr abandons Lefebvre. He is 'sentenced to ... wander in space' (ibid: 23). ${ }^{3}$

Being lost in space takes its toll, judging from the ways in which Lefebvre is influencing theorizations of space and politics, and in the context of recent urban uprisings and occupations. For instance, Merrifield - who draws direct inspiration from Lefebvre - has proposed a new, 'magical' Marxism: 'a Marxism that no longer calls itself "scientific" and has given up on the distinction between form and content, between appearance and essence ... a Marxism that opens up the horizons of the affirmative and reaches out beyond the dour realism of critical negativity' (Merrifield 2011b: 1). The implication of expurgating Marx in favor of more enigmatic, more affirmative notion of emancipatory politics is of critical importance. One danger is that anti-capitalism becomes a matter of 'resistance for the sake of resistance': a posture that demands no prior (anti-)ontological critique (Bonefeld 2012). ${ }^{4}$ 


\section{Harvey: Capitalist Urbanization and the Spatiality of Class Struggle}

The hallmark of Harvey's extensive writings on crises in general - and the current crisis, especially - has precisely been his recourse to substantive social theorization, and, almost exclusively, to Marx (e.g. Harvey 1982; 1985; 2010). Harvey's analysis of the current crisis appears to validate what is perhaps his own signal contribution since the early 1970s: namely, how urbanization has been crucial to the spatial organisation of capitalist production and reproduction, and how urban centres came to play a role as 'active moments' in the dynamics of overaccumulation-devaluation. ${ }^{5}$

While we can assuredly acknowledge both Harvey and Lefebvre's contribution to thinking about space in dialectical terms, we can also begin to distantiate them - and notwithstanding Harvey's recent tribute to 'Lefebvre's vision' in Rebel Cities (2012). Even this book attests to Harvey's own consistency insofar as it continues to foreground the question of capitalist time over capitalist space. Take this passage, published almost thirty years ago:

[T] he circulation of capital makes time the fundamental dimension of human affairs. Under capitalism, after all, it is socially necessary labor time that forms the substance of value, surplus labor time that lies at the origin of profit, and the ratio of surplus labor time to socially necessary turnover time that defines the rate of profit and, ultimately, the average rate of interest ... Under capitalism, therefore, the meaning of space and the impulse to create new spatial configurations of human affairs can be understood only in relation to such temporal requirements. The phrase 'annihilation of space by time' does not mean that the spatial dimension becomes irrelevant. It poses, rather, the question of how and by what means space can be used, organized, created and dominated to fit the rather strict temporal requirements of the circulation of capital (Harvey 1985: 37).

Fast-forward to 2012 and Rebel Cities: Harvey discusses 'the common'. Against Hardt and Negri (2009), he foregrounds the question of the production and appropriation of wealth (a matter of time) over that of the common (and its spatial counterpart, 'the enclosure'): 'the real problem lies with the private character of property rights and the power these rights confer to appropriate not only the labor but also the collective product of others. Put another way, the problem is not the common per se, but the relations between those who produce and capture it at a variety of scales and those who appropriate it for private gain' 
(Harvey 2012: 78-79). He also proposes that the urban process be re-conceptualized so as to allow for a reinvigoration of the Marxian notion of class struggle and so as to point towards an effective political strategy for the working class (broadly conceived):

There is a seamless connection between those who mine the iron ore that goes into the steel that goes into the construction of the bridges across which the trucks carrying commodities travel to their final destinations of factories and homes for consumption. All of these activities (including spatial movement) are productive of value and of surplus value ... Organized, these workers would have the power to strangle the metabolism of the city (ibid.: 130-131).

To summarize Harvey's longstanding position: capital, impelled by the 'coercive laws of competition', constructs its own spatial landscape consisting of physical but also social infrastructures that are appropriate, for a time at least, to its drive to accumulate relative surplus-value - and with all the implications that brings for the spatial organization of the international division of labor, for uneven geographical development, and for crisis formation (Harvey 1982: chapter 12). In so doing, however, capital produces a terrain in and through which all workers involved in the production and circulation process - within or together with urban social movements demanding the right to the city or to urban commons - can organize and engage in struggle so as to act as a barrier to the process of capital accumulation. At the heart of the passage on class struggle from Rebel Cities, quoted above, is a logic of temporal disruption, of blockage, of using capital's metabolic dependence upon produced social and physical infrastructures (as a means of meeting its own immanent temporal requirements) against it. What emerges, therefore, is a different conceptualization of the politics of space to that offered by Lefebvre; oriented, as Harvey's is, to the necessarily prior and temporal understanding of capital accumulation as the determinant of the production of space, of urbanization, and of the periodic 'creative destruction' of a landscape of physical and social infrastructures built 'in its own image' (Harvey 1985: 162). It also, certainly, contradicts any suggestion that prior substantive theorization be ditched by anti-capitalist movements: 'Citizen and comrade can march together in anti-capitalist struggle ... But this can occur only if we become, as [urban sociologist, Robert] Park long ago urged, more "conscious of the nature of our task", which is to collectively to build the socialist city on the ruins of destructive capitalist urbanization' (Harvey 2012: 153). 


\section{On Critical Thought and the Enigma of Class Struggle}

It appears, then, that Harvey's work might be considered as a relational and spatially conscious corrective to Lefebvre's 'reproductionism'. Indeed, Harvey's recent writings appear to chime with Kerr's (1994: 34) verdict that 'space will be an "instrument" in the struggle for change, but certainly will not be the "goal" of that struggle, as Lefebvre suggests'. But the possibility of a synthesis between Harvey's theorization of the production of space in capital's own image and of negative dialectics - as championed John Holloway, for example - requires that potentially obstructive issues be addressed first.

Holloway's argument in Crack Capitalism develops his long-standing championing of an anti-dogmatic 'open Marxism', and of negative dialectics as the proper basis of immanent critique. Elsewhere, he writes: 'Dialectics means thinking the world from that which does not fit, from those who do not fit, those who are negated and suppressed, those whose insubordination and rebelliousness break the bounds of identity, from us who exist in-andagainst-and-beyond capital' (Holloway 2009: 15). Werner Bonefeld similarly emphasizes that negative dialectics are a necessary means of illuminating the determinate movement of negativity and of engaging in critique. He writes, 'however much the objective world has autonomized itself from acting individuals, it remains a form of human practice' (Bonefeld 2012: 129). It follows therefore, that 'critical theory rejects as total ideology the idea of resistance for the sake of resistance. It demands a recognition of social contents' (ibid.: 132).

In Castree's (2006) interpretation, most of Harvey's work until the late 1980s did reflect such a mode of immanent critique insofar as 'it seems to be a rather austere dissection of capitalism's temporalities and spatialities, [and] it is also a non-moralistic indictment of this mode of production'; 'it shows that system to be crisis-prone and self-negatory' (ibid.: 259). But in subsequent writings, in Castree's opinion, Harvey - confronting a 'crisis of Marxism' within and outside academia - opted for 'criticism' (the resort to extraneous values and normative judgments) as a 'useful second best' to critique (ibid.: 260). Of course, in negative dialectics the very notion that it is possible to judge an object (capitalism) from a vantage point that stands outside it, and therefore outside of the very conceptuality of the object itself - as is implied in Castree's distinction - is a fallacy (Bonefeld 2009). But this does then beg the question of the extent to which Castree is able to make such an allegation because Harvey's himself conceives of critical thought in realist epistemological terms; that is, whether Harvey's project to expose the objective irrationality of capitalism presupposes the 
separation of subject and object, which negative dialectics denounces. Castree (ibid.: 264) does suggest 'that most talismanic of Marxist ideas - an insurgent working class actor who is capitalism's gravedigger - has been steadily attenuated in Harvey's work as the years have gone by ... [Ironically], his is a critical theory that lacks a subject'. Is Harvey's call for a broader conceptualization of class struggle, in Rebel Cities for example, in some way symptomatic of a subject-object dualism? And, in trying to make his earlier critique more 'relevant' (Castree 2007), has Harvey fallen prey to the view that 'social theory requires "validation by means of empirical corroboration" (Callinicos 2005: 85), [which] debases the critical purpose of thought' (Bonefeld 2012: 128)?

Kerr (1996) appears to corroborate such a view, and he questions even Harvey's works that Castree suggests do fulfill the role of critique. In Harvey's keystone The Limits to Capital (1982), Kerr identifies two fundamental and related dualisms: between the twin themes of accumulation and class struggle, and between theory and history. For Kerr, these compromise the status of Harvey's theory as critique since they exhibit how he constructs theory first, so as to unfold the law-like character of capital accumulation (complete with its production of space), only then to switch vantage point to that of the working class and the history of its struggle over the urban process. Hence, 'it is not clear what constitutes that class struggle nor where it has come from in order to be able to "enter into" and "fight against the effects of these laws". Furthermore, if a focus on struggle leaves theory behind, how is it possible to "understand' that struggle?' (Kerr 1996: 70). From the point of view of negative dialectics, "the "laws of accumulation" are nothing else than the movement of the class struggle. There is no separation of accumulation and struggle, of concept and history' (ibid.).

\section{Conclusions}

Holloway's reference to spatiality, mentioned in the introduction, perhaps hints at the casual manner in which 'space' - an extraordinarily complex and elusive concept - features in much social theory and commentaries on contemporary urban uprisings, occupations of public squares, and so on. In attempting to ground an understanding of what might be intrinsically spatial about saying 'no' to capital and to austerity, I have shown how a version of dialectical negativity informs the work of Henri Lefebvre, and his work on space in particular. However, in conceiving of the dialectic as 'a general method ... applied by [Marx] in only a limited number of fields' (Shields 1999: 109, emphasis added), Lefebvre saw fit to formulate 
a method for the analysis of space in itself and with temporalities of its own, autonomized from the socio-temporal determinations of the production of value. Despite grasping the critical labor of the negative, albeit as a point of principle, this move on Lefebvre's part puts him at odds with Bonefeld and Holloway's open Marxism: ${ }^{6}$ 'If the social is inherently spatial and can only exist as such, then the former cannot be juxtaposed to the latter; social contradictions do not exist in space but express themselves spatially' (Kerr 1994: 33). Critique requires, instead, thought that foregrounds the question of abstract time and only then asks after the determinations at play in the production of space in capital's own image. Harvey has arguably achieved more in this regard than any other theorist. If he is right to warn against neglecting the spatiality of movement and at the risk of courting political irrelevance, perhaps, at the very least, exponents of negative dialectics will have to be more explicit about the spatiality of interstitial revolution and of communization. However, any attempt to synthesize Harvey's analysis of the 'laws of motion' of capital - complete with his theorization of the urban process and of space as an active moment in the dynamics of crisis formation - with a negative, interstitial notion of anti-capitalist revolution must first have to reassure others, and perhaps Harvey included, of the importance of negative dialectics, and of the need to resist the separation of structure and struggle - precisely because the stakes are high. 


\section{Notes}

${ }^{1}$ With thanks to Tom Houseman, Alex Loftus, Tom Purcell, Ramon Ribera-Fumaz, Miguel Robles-Durán and Japhy Wilson for their criticism of an earlier version.

${ }^{2}$ Kerr is paraphrasing Smith (1990: xv).

${ }^{3}$ Lefebvre did focus largely upon questions of time in his late works (see Lefebvre 1992).

${ }^{4}$ Though not explicitly influenced by Lefebvre, Swyngedouw (2011), for example, suggests that recent urban anti-austerity movements precisely represent an affirmation: one of 'the equality of each and every one qua speaking beings - a condition that is predicated upon affirming difference and the dissensual foundation of politics'. For Swyngedouw, then, interruptions that properly politicize public space require no prior grounding in social theory, no 'recognition of social content' a la Bonefeld. In enacting politics 'under the aegis of equality' - thus interrupting the normalized order of, what Rancière has termed, 'the Police' - such protest 'constitutes a proper political sequence; one that can be thought and practiced irrespective of any substantive social theorization' (ibid.).

5 'Much of my own work ... has been about trying to track exactly such a process, to understand how capital builds a geographical landscape in its own image at a certain point in time only to have to destroy it later in order to accommodate its own dynamic of endless capital accumulation, strong technological change, and fierce forms of class struggle (Harvey 2000: 177).

${ }^{6}$ A crucial point missed by Charnock (2010). 


\section{References}

Bonefeld, Werner. 1993. The Recomposition of the British State in the 1980s. Aldershot: Dartmouth.

Bonefeld, Werner. 2009. "Emancipatory Praxis and Conceptuality in Adorno", in Negativity and Revolution: Adorno and Political Activism, edited by John Holloway, Fernando Metamoros and Sergio Tischler, 122-147. London: Pluto.

Bonefeld, Werner. 2012. "Negative Dialectics in Miserable Times: Notes on Adorno and Social Praxis". Journal of Classical Sociology 12, no. 1: 122.

Brenner, Neil. 2008. "Henri Lefebvre's Critique of State Productivism”, in Space, Difference, Everyday Life: Reading Henri Lefebvre, edited by Kanishka Goonewardena, Stefan Kipfer, Richard Milgrom and Christain Schmid, 231-249. London: Routledge.

Callinicos, Alex. 2005. “Against the New Dialectic”. Historical Materialism 13, no. 2: 41.

Castree, Noel. 2006. "The Detour of Critical Theory", in David Harvey: A Critical Reader, edited by Noel Castree and Derek Gregory, 247-269. Oxford: Blackwell.

Castree, Noel. 2007. "David Harvey: Marxism, Capitalism and the Geographical Imagination". New Political Economy 12, no. 1: 97.

Charnock, Greig and Ramon Ribera-Fumaz. 2011. "A New Space for Knowledge and People? Henri Lefebvre, Representations of Space, and the Production of 22@Barcelona”. Environment and Planning D: Society and Space 29, no. 3: 613.

Charnock, Greig. 2010. "Challenging New State Spatialities: The Open Marxism of Henri Lefebvre”. Antipode 42, no. 5: 1279.

Elden, Stuart. 2004a. Understanding Henri Lefebvre: Theory and the Possible. London: Continuum.

Elden, Stuart. 2004b. "Between Marx and Heidegger: Politics, Philosophy and Lefebvre's The Production of Space". Antipode 36, no. 1: 86.

Hardt, Michael and Antonio Negri. 2009. Commonwealth. Cambridge: Harvard University Press.

Harvey, David. 1974. "Class-Monopoly Rent, Finance Capital and the Urban Revolution". Regional Studies 8, nos. 3-4: 239.

Harvey, David. 1982. The Limits to Capital. Oxford: Blackwell.

Harvey, David. 1985. The Urbanization of Capital: Studies in the History and Theory of Capitalist Urbanization 2. Oxford: Blackwell.

Harvey, David. 2000. Spaces of Hope. Edinburgh: Edinburgh University Press.

Harvey, David. 2006. "Space as a Keyword", in David Harvey: A Critical Reader, edited by Noel Castree and Derek Gregory, 270-293. Oxford: Blackwell.

Harvey, David. 2010. The Enigma of Capital and the Crises of Capitalism. London: Profile Books.

Harvey, David. 2012. Rebel Cities: From the Right to the City to the Urban Revolution. London: Verso. 
Holloway, John. 2009. "Why Adorno?", in Negativity and Revolution: Adorno and Political Activism, edited by John Holloway, Fernando Metamoros and Sergio Tischler, 12-17. London: Pluto.

Holloway, John. 2010. Crack Capitalism. London: Pluto.

Kerr, Derek. 1994. "The Time of Trial by Space? Critical Reflections on Henri Lefebvre's Epoch of Space". Common Sense 15: 18. commonsensejournal.org.uk/files/2010/08/CommonSense15.pdf.

Kerr, Derek. 1996. "The Theory of Rent: From Crossroads to The Magic Roundabout". Capital \& Class 20, no. 1: 59.

Lefebvre, Henri. 1976. The Survival of Capitalism: Reproduction of the Relations of Production. Translated by Frank Bryant. London: Allison \& Busby.

Lefebvre, Henri. 1991. The Production of Space. Translated by Donald Nicholson-Smith. Oxford: Blackwell.

Lefebvre, Henri. 1992. Éléments de rythmanalyse. Paris: Éditions Syllepse.

Lefebvre, Henri. 1996. Writings on Cities: Henri Lefebure. Selected, translated and introduced by Eleonore Kofman and Elizabeth Lebas. Oxford: Blackwell.

Lefebvre, Henri. 2000. Everyday Life in the Modern World. Translated by Sacha Rabinovitch. London: Athlone Press.

Lefebvre, Henri. 2003. The Urban Revolution. Translated by Roberto Bononno. Minneapolis: University of Minnesota Press.

Lefebvre, Henri. 2008. Critique of Everyday Life. Vols. I-III. Translated by John Moore and Gregory Elliott. London: Verso.

Lefebvre, Henri. 2009. 'Reflections on the Politics of Space', in State, Space, World: Selected Essays/Henri Lefebure, edited by Neil Brenner and Stuart Elden, 167-184. Minneapolis: University of Minnesota Press.

Merrifield, Andy. 2011a. "The Right to the City and Beyond: Notes on a Lefebvrian Reconceptualization". City 15, nos. 3-4: 468.

Merrifield, Andy. 2011b. Magical Marxism: Subversive Politics and the Imagination. London: Pluto.

Ronneberger, Klaus. 2008. "Henri Lefebvre and Urban Everyday Life: In Search of the Possible", in Space, Difference, Everyday Life: Reading Henri Lefebure, edited by Kanishka Goonewardena, Stefan Kipfer, Richard Milgrom and Christian Schmid, 134-146. London: Routledge.

Shields, Rob. 1999. Lefebure, Love and Struggle: Spatial Dialectics. London: Routledge.

Smith, Neil. 1990. Uneven Development: Nature, Capital, and the Production of Space. Second Edition. Oxford: Blackwell.

Stanek, Lukasz. 2011. Henri Lefebvre on Space: Architecture, Urban Research and the Production of Theory. Minneapolis: University of Minnesota Press. 
Swyngedouw, Erik. 2011. "Every Revolution has its Square", cities@manchester, March 18. citiesmcr.wordpress.com/2011/03/.

Zuss, Mark (2005) “A Blinking Sphinx: Theoretical Curiosity in Postwar Marxism”. Situations: Project of the Radical Imagination 1, 1: 47. 